\title{
Perspectives on the Perennial Challenge of Muslim Education
}

\section{Ssekamanya Siraje Abdallah ${ }^{*}$}

For hundreds of years, Muslim thinkers have been grappling with the crucial question of where should Muslims focus their efforts in education: Should they focus on the lower levels; giving a firm foundation to children from pre-schools all the way through high school?, or should they focus on higher education, which directly equips students with high level knowledge and skills to become leaders and skilled workers? Like the age-old chicken and egg riddle, there are no simple answers to this question. In 1977, the greatest Muslim minds at that time convened to consider this issue, inter alia. Among the most profound ideas in that meeting was Professor Syed Muhammad Naquib al-Attas's model of an Islamic university, which he later elaborated in his seminal works (Al-Attas, 1978; 1979; 1993; and Daud, 1998). His view was a true university, established upon the proper principles of Islamic epistemology and spirituality, would be the foundation for enlightening the ummah and ridding it of the evil influences of secularism.

That almost forty years after the Mecca conference of 1977 we are still grappling with the same issues should not be a cause for disappointment. Such issues are not easy to resolve. Until now educational philosophers are dealing with the questions posed more than two millennia ago by Socrates, Plato and Aristotle. Of course we cannot deny that much progress has been made since the Mecca conference, especially in the area of Muslim higher education.

\footnotetext{
${ }^{*}$ Kulliyyah of Education, International Islamic University Malaysia.
} 
While authors of the papers in this volume did not intend to deal with that age-old problem mentioned above, it somehow forces itself on their works. Two of the papers deal with pre-service and in-service teacher education and training as well as quality issues in higher education. Another two papers deals with aspects of organization, management and leadership of higher education as well as lower education institutions. Another two papers deal with traditional Islamic education institutions and programs. Finally, we have a review of the contribution of Ali Shari'ati, a prominent Iranian scholar whose ideas were very influential in different parts of the Muslim world towards the end of the twentieth century.

The first article by Abdul Razaq Ahmad and Najamuddin $\mathrm{Hj}$. Bachora dealt with the issue of intercultural relationships among trainee teachers at the Malaysian Institutes of Teacher Education (ITE). This is a very important study considering that Malaysia is highly regarded as a moderate and successful Muslim state where people of different ethnicities, cultures and faith live together in harmony. It acquires even greater significance due to its concentration of teacher-trainees. Teachers are the heart and soul of a nation. If teachers are bigoted, racist, and extremist, their students will follow suit. To change a nation, we have to start by changing its teachers.

Dealing with a different aspect of the issue of diversity in relation to trainee teachers, the second paper by Supiah Saad, Siti Rafiah Abd Hamid and Khamsiah Ismail examined how much do Malaysian in-service trainee teachers and pre-service trainee teachers know about children with special needs. While Malaysia is one of the developing countries with progressive policies and practices related to children with special needs, the knowledge levels of teachers can have a significant impact on the success or failure of those policies. Thus this effort to assess the teachers' knowledge and preparedness about children with special needs will help to influence the development of teacher training programs.

The third article by Bakare Kazeem Kayode and Che Noraini Hashim attempts to critically analyze issues and challenges of quality assurance confronting Islamic universities. In this age of globalization and university rankings, quality assurance has become permanent fix- 
ture in almost all institutions of higher learning. While many academics criticize it, accusing it to be a new form of western hegemony or a tool of capitalists, the truth is that it is here to stay. Moreover, we cannot deny that quality assurance models ultimately force institutions to improve their processes and outcomes. A good contribution of this paper is that it relates quality assurance with the issue of leadership.

The fourth paper by Ahmad Suhail Al-Anshory and Hairuddin Mohd. Ali deals with the issue of leadership in lower education. It examined the important concept of followership among teachers at a private, "integrated" Islamic school at Kuala Lumpur, Malaysia. While many people emphasize the role of leadership, they neglect followership, forgetting that leaders are made by followers. The findings of this research, which showed that all of the major followership styles were represented, will be of great use for those interested in strengthening the leadership of Muslim educational institutions.

From a modern "integrated" Islamic school in Kuala Lumpur, Malaysia, the fifth paper by Muhammad Ikhwanuddin and Che Noraini Hashim takes us to a traditional Islamic "school" in Indonesia. Its subject matter is "traditional" but very important. While most Muslims believe that the Qur' an is the source of their faith, and whereas many parents are sending their children to commit the Qur'an to memory, the sad fact is that very few Muslims actually understand the Qur'an. This case study of a successful institution where non-Arab students learn not only how to memorize the Qur'an but also how to understand its contents (and hopefully act upon them) is absolutely significant.

The sixth article by Muhammed Haron is a review of the seminal ideas of the South African Muslim scholar, Yusef Waghid. The contribution of the latter scholar is significant in that as a product of both the traditional Islamic and modern western systems of education, he found a way of effectively synthesizing the two. He has not only worked in the academic world, creating and discussing ideas, but has also been at the forefront of dealing with real-world issues and working with other scholars to find effective solutions to the problems facing the Muslim community in southern Africa. Yusef Waghid's ideas can inform efforts to bring Muslim education to the next level. 
The volume ends with a book review by Tahraoui Ramdane and Merah Souad. The book reviewed is a collection of articles by the great Iranian ideologue of the late twentieth century, Dr. Ali Shari'ati. We hope that all these contributions will stimulate more debate and further research about the issues raised.

\section{References}

al-Attas, S. M. N. (1978). Islam and Secularism. Kuala Lumpur: Muslim Youth Movement of Malaysia (ABIM).

Al-Attas, S. M. N. (1979). Preliminary thoughts on the nature of knowledge and the definition and aims of education. Aims and objectives of Islamic education, 19-47.

Al-Naquib Al-Attas, S. M. (1979). Aims and objectives of Islamic education. Sevenoaks: Hodder and Stoughton.

al-Attas, S. M. N. (1993). Islam and Secularism. 2nd Ed. Kuala Lumpur: International Institute of Islamic Thought and Civilization (ISTAC).

Daud, W. M. N. W. (1998). The educational philosophy and practice of Syed Muhammad Naquib al-Attas: An exposition of the original concept of Islamization. International Inst. of Islamic Thought and Civilization. 